\title{
Physiopathological modulators of amyloid aggregation and novel pharmacological approaches in Alzheimer's disease*
}

\author{
FERNANDA G. DEFELICE and SÉRGIO T. FERREIRA \\ Department of Medical Biochemistry, Institute of Biomedical Sciences \\ Federal University of Rio de Janeiro, 21944-590 Rio de Janeiro, RJ, Brazil \\ Manuscript received on December 26, 2001; accepted for publication on January 3, 2002, \\ contributed by SÉRgIO T. FERREIRA**
}

\begin{abstract}
The biological mechanisms underlying the neuropathology of Alzheimer's disease (AD) are complex, as several factors likely contribute to the development of the disease. Therefore, it is not surprising that a number of different possible therapeutic approaches addressing distinct aspects of this disease are currently being investigated. Among these are ways to prevent amyloid aggregation and/or deposition, to prevent neuronal degeneration, and to increase brain neurotransmitter levels. Here, we discuss possible roles of endogenous modulators of $\mathrm{A} \beta$ aggregation in the physiopathology of $\mathrm{AD}$ and some of the strategies currently under consideration to interfere with brain levels of $\beta$-amyloid, its aggregation and neurotoxicity.
\end{abstract}

Key words: Alzheimer's disease, $\mathrm{A} \beta$ peptide, aggregation, neurotoxicity, physiopathological modulators.

\section{INTRODUCTION}

Alzheimer's disease (AD) is characterized by a slow, progressive decline in cognitive function and behavior. Progression of the disease leads to marked deterioration in memory, judgement, attention and speech and to behavioral changes including depression and psychiatric disturbances. AD poses a significant challenge to health care systems worldwide. It is estimated that about 20 million people currently suffer from dementia caused by AD (Haass and De Strooper 1999), with $20 \%$ of the individuals above 75 years old (and $\sim 50 \%$ of those above 85 ) at risk of developing the disease. Despite considerable efforts aiming at understanding the molecular basis and physiopathology of $\mathrm{AD}$, there are currently no

Correspondence to: Sérgio T. Ferreira

E-mail: ferreira@bioqmed.ufrj.br

*Invited paper

**Member of Academia Brasileira de Ciências effective, clinically accepted treatments to cure it or stop its progression.

The $\beta$-amyloid peptide (A $\beta$ ) plays a central role in the neuropathology of AD (Selkoe 1994, 1999, Yankner 1996, Verbeek et al. 1997). A $\beta$ is a peptide of 39-43 amino acid residues produced by proteolytic cleavage of a large precursor known as the amyloid precursor protein (APP), encoded by a gene located on chromosome 21 in humans (Glenner and Wong 1984) (Fig. 1). APP is an integral membrane glycoprotein, with a short cytoplasmic C-terminal tail and a large extracellular N-terminal domain (Kang et al. 1987). Enzymes known as secretases are responsible for proteolysis of APP and release of $\mathrm{A} \beta$ (Verbeek et al. 1997). The first 28 amino acid residues of $\mathrm{A} \beta$ originate from the extracellular domain of APP and the remaining 11-15 residues originate from the transmembrane region of APP (Kang et al. 1987). A $\beta$ is released follow- 
ing cleavage of APP at positions 597 and 637-639 by $\beta$ - and $\gamma$-secretases, respectively (Verbeek et al. 1997, Nunan and Small 2000). $\beta$-secretase has recently been identified as an aspartic protease (Vassar et al. 1999, Yan et al. 1999, Sinha et al. 1999, Lin et al. 2000). $\gamma$-secretase may cleave APP at the Cterminal end of $\mathrm{A} \beta$ at four different positions, giving rise to $\mathrm{A} \beta$ peptides that are $39-43$ amino acids long. The exact position of C-terminal cleavage appears critical to the development of $\mathrm{AD}$, since generation of the more amyloidogenic peptides (such as $\mathrm{A} \beta_{1-42}$ or $\left.\mathrm{A} \beta_{1-43}\right)$ is strongly correlated with the development of AD (Scheuner et al. 1996, Small and McLean 1999, Nunan and Small 2000). The precise molecular identity of $\gamma$-secretase remains elusive. However, recent evidence suggests that presenilins 1 and 2, acting in association with another protein known as nicastrin, may constitute the $\gamma$-secretase complex responsible for the release of $\mathrm{A} \beta$ (Yu et al. 2000).

$\mathrm{A} \beta$ is the major protein constituent of the senile plaques found in the brains of $\mathrm{AD}$ patients (Glenner and Wong 1984, Masters et al. 1985). A $\beta$ forms characteristic non-covalent fibrillar aggregates both in vitro and in vivo, and its aggregation and ensuing amyloid deposition in the brain have been related to AD neurotoxicity (Pike et al. 1993, Lorenzo and Yankner 1994, Geula et al. 1998) (Fig. 1). In vitro, amyloid fibril formation can be influenced at various stages by factors that either stimulate or inhibit aggregation. Such factors include peptide concentration, changes in its primary sequence, $\mathrm{pH}$ and interactions with various biomolecules (for examples, see Levy et al. 1990, Wisniewski et al. 1991, Fraser et al. 1991, 1992, 2001, Inouye et al. 1993, Evans et al. 1995). It is likely that the development of amyloid plaques in vivo also depends on the combined actions of at least some of these components. Thus, identifying physiological factors involved in $\mathrm{A} \beta$ aggregation and the interactions that are important for amyloid stability may reveal possible targets for therapeutic intervention and prevention of amyloid aggregation and toxicity.

\section{PHYSIOPATHOLOGICAL MODULATORS OF AMYLOID AGGREGATION}

Many different biomolecules (including proteins, proteoglycans, lipids, metals and other small molecules) have been reported to be associated with amyloid plaques in AD brains. While it is possible that some of these molecules may be related to secondary events in amyloid deposition, in vitro and in vivo studies have demonstrated that many of them may actually regulate $\mathrm{A} \beta$ aggregation (Table I). It should be noted that a delicate balance exists between $\mathrm{A} \beta$ production, aggregation and clearance in the brain, so that even agents that have a relatively small effect on $\mathrm{A} \beta$ aggregation in vitro may play significant roles in the regulation of those events in vivo.

It has been shown that certain plasma proteins, at physiological concentrations, control $\mathrm{A} \beta$ polymerization (Bohrmann et al. 1999). Albumin, $\alpha_{1}$ antitrypsin, $\mathrm{IgG}$, and $\operatorname{IgA}$ are potent inhibitors of $\mathrm{A} \beta$ fibrillogenesis, with $\mathrm{IC}_{50}$ values substantially lower than their plasma concentrations (Bohrmann et al. 1999). However, these proteins are present at low concentrations in cerebrospinal fluid, and possibly have little or no effect on $\mathrm{A} \beta$ aggregation. For example, although albumin is the most abundant protein in cerebrospinal fluid, it is present at a concentration below its $\mathrm{IC}_{50}$ value, suggesting that it might cause only partial inhibition of $\mathrm{A} \beta$ polymerization (Bohrmann et al. 1999). The acute phase response protein, $\alpha_{1}$-antichymotrypsin, is upregulated as a result of inflammatory processes and belongs to the serpin family of serine protease inhibitors. Co - localization of $\alpha_{1}$ - antichymotrypsin with amyloid deposits has been reported exclusively in Alzheimer's disease (Abraham et al. 1988), suggesting a specific interaction with $\mathrm{A} \beta$. When present at high concentrations, $\alpha_{1}$-antichymotrypsin enhances amyloid aggregation (Ma et al. 1994, Janciauskiene et al. 1996). By contrast, at low concentrations $\alpha_{1}$-antichymotrypsin inhibits amyloid formation and disaggregates previously formed aggregates (Fraser et al. 1993, Eriksson et al. 1995, 

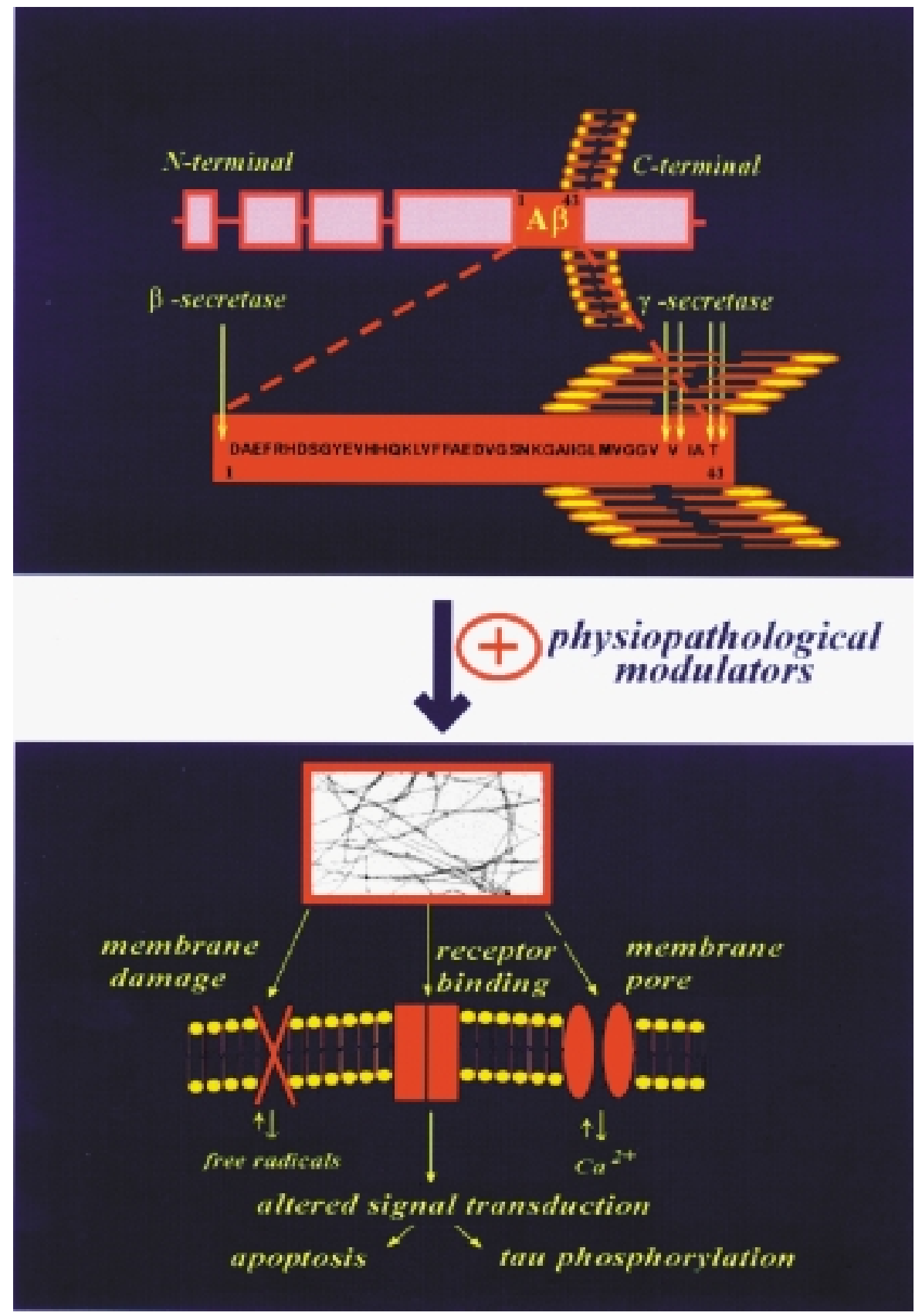

Fig. 1 - Proposed topology of APP in the plasma membrane, A $\beta$ production and possible mechanisms of neurodegeneration. Upper panel: The plasma membrane-anchored APP (shown in pink) is cleaved by $\beta$ - and $\gamma$-secretases (vertical arrows) to yield the 39-43 amino acid residue $\mathrm{A} \beta$ peptide fragment (red). Aggregation of $\mathrm{A} \beta$ is stimulated by physiopathological modulators (as discussed in the text). Lower panel: Aggregated $\mathrm{A} \beta$ leads to neurodegeneration through a number of possible mechanisms, including membrane damage, binding to cell-surface receptors and activation of intracellular signal transduction events and/or alteration of ion homeostasis. These events ultimately lead to hyperphosphorylation of tau and cell death. 
TABLE I

Physiopathological modulators of $\mathbf{A} \beta$ aggregation $^{1}$

\begin{tabular}{|c|c|c|c|}
\hline Modulator & $\begin{array}{c}\mathrm{A} \beta \text { secondary } \\
\text { structure }\end{array}$ & $\begin{array}{c}\text { Effect on } \\
\text { A } \beta \text { aggregation }\end{array}$ & $\begin{array}{c}\mathrm{A} \beta \text { interaction } \\
\text { domain }\end{array}$ \\
\hline \multicolumn{4}{|l|}{ Plasma proteins } \\
\hline albumin & $\mathrm{n} / \mathrm{d}$ & $\downarrow$ & $1-28$ \\
\hline$\alpha_{1}$-antitrypsin & $\mathrm{n} / \mathrm{d}$ & $\downarrow$ & $11-28$ \\
\hline IgG & $\mathrm{n} / \mathrm{d}$ & $\downarrow$ & $\mathrm{n} / \mathrm{d}$ \\
\hline $\operatorname{IgA}$ & $\mathrm{n} / \mathrm{d}$ & $\downarrow$ & $\mathrm{n} / \mathrm{d}$ \\
\hline$\alpha_{1}$-antichymotrypsin & random & $\uparrow / \downarrow$ & $11-28,29-42$ \\
\hline$\alpha_{2}$-macroglobulin & random & $\downarrow$ & $11-28$ \\
\hline serum amyloid A & $\mathrm{n} / \mathrm{d}$ & $\uparrow$ & $1-28$ \\
\hline \multicolumn{4}{|l|}{ Glicosaminoglycans } \\
\hline heparan sulfate & $\beta$-sheet & $\uparrow$ & $13-16$ \\
\hline keratan sulfate & $\beta$-sheet & $\uparrow$ & $\mathrm{n} / \mathrm{d}$ \\
\hline dermatan sulfate & $\beta$-sheet & $\uparrow$ & $\mathrm{n} / \mathrm{d}$ \\
\hline chondroitin sulfate & $\beta$-sheet & $\uparrow$ & $13-16$ \\
\hline \multicolumn{4}{|l|}{ Apolipoproteins } \\
\hline apoE & $\beta$-sheet & $\downarrow / \uparrow$ & $29-42$ \\
\hline apoJ & $\beta$-sheet & $\downarrow / \uparrow$ & $29-42$ \\
\hline apoA-1 & $\mathrm{n} / \mathrm{d}$ & $\downarrow$ & $\mathrm{n} / \mathrm{d}$ \\
\hline Complement C1q & $\mathrm{n} / \mathrm{d}$ & $\uparrow$ & $1,3,7,11$ \\
\hline Acetylcholinesterase & $\mathrm{n} / \mathrm{d}$ & $\uparrow$ & $\mathrm{n} / \mathrm{d}$ \\
\hline Laminin & $\mathrm{n} / \mathrm{d}$ & $\downarrow$ & $\mathrm{n} / \mathrm{d}$ \\
\hline Entactin & random & $\downarrow$ & $\mathrm{n} / \mathrm{d}$ \\
\hline \multicolumn{4}{|l|}{ Phospholipids $^{2}$} \\
\hline PS & random & $\uparrow$ & $29-42$ \\
\hline PI & $\beta$-sheet & $\uparrow$ & $29-42$ \\
\hline $\mathrm{PC}$ & random & no change & $\mathrm{n} / \mathrm{d}$ \\
\hline $\mathrm{PE}$ & random & no change & $\mathrm{n} / \mathrm{d}$ \\
\hline $\mathrm{PA}$ & random & $\uparrow$ & $29-42$ \\
\hline IS & $\alpha$-helix & $\begin{array}{l}\text { stabilize small } \\
\text { aggregates }\end{array}$ & $\mathrm{n} / \mathrm{d}$ \\
\hline
\end{tabular}

Lukacs and Christianson 1996). In the latter case, independent studies have shown that interactions between $\alpha_{1}$-antichymotrypsin and $\mathrm{A} \beta$ sequences 11 28/29-42 are involved in inhibition of fibrillogenesis (Lukacs and Christianson 1996, Janciauskiene et al. 1998). Recent work has also shown that transgenic mice expressing human APP and overexpressing $\alpha_{1}$-antichymotrypsin develop a significantly higher number of amyloid plaques, and at earlier ages than mice expressing only human APP 
TABLE I ( continuation )

\begin{tabular}{cccc}
\hline Modulator & $\begin{array}{c}\mathrm{A} \beta \text { secondary } \\
\text { structure }\end{array}$ & $\begin{array}{c}\text { Effect on } \\
\mathrm{A} \beta \text { aggregation }\end{array}$ & $\begin{array}{c}\mathrm{A} \beta \text { interaction } \\
\text { domain }\end{array}$ \\
\hline Gangliosides & & & \\
GM1 & $\beta$-sheet $/ \alpha$-helical & $\downarrow$ & $\mathrm{n} / \mathrm{d}$ \\
GM2 & random & no change & $\mathrm{n} / \mathrm{d}$ \\
GM3 & random & no change & $\mathrm{n} / \mathrm{d}$ \\
GD1a & random & no change & $\mathrm{n} / \mathrm{d}$ \\
GT1b & random & no change & $\mathrm{n} / \mathrm{d}$ \\
Glicerol/TMAO & $\beta$-sheet & $\uparrow$ & $\mathrm{n} / \mathrm{d}$ \\
Metals & & & \\
$\mathrm{Zn}^{2+}$ & $\beta$-sheet & $\uparrow$ & His13, His14 \\
Cu ${ }^{2+}$ & $\beta$-sheet & $\uparrow$ & His13 \\
$\mathrm{Fe}^{3+}$ & $\beta$-sheet & $\uparrow$ & His13 \\
\hline
\end{tabular}

${ }^{1}$ Appropriate references are cited in the text (Section 2). ${ }^{2} \mathrm{PS}$, phosphatidylserine; PI, phosphatidylinositol; PC, phosphatidylcholine; PE, phosphatidylethanolamine; PA, phosphatidic acid; IS, inositol stereoisomers.

(Nilsson et al. 2001). Another acute fase protein, $\alpha_{2}$-macroglobulin, associates with $\mathrm{A} \beta$, prevents fibril formation (Hughes et al. 1998) and attenuates $\beta$-amyloid peptide neurotoxicity in cultured rat fetal cortical neurons (Du et al. 1998).

Different types of glycosaminoglycan (GAG) chains, including heparan sulfate (Snow et al. 1988), keratan sulfate (Snow et al. 1996), dermatan sulfate (Snow et al., 1992) and chondroitin sulfate (DeWitt et al. 1993) are found in association with amyloid plaques in $\mathrm{AD}$. A number of studies have shown that GAGs promote formation and/or stabilize amyloid fibrils (Fraser et al. 1992, 2001, Buee et al. 1993a, b, Brunden et al. 1993, Snow et al. 1995, Castillo et al. 1997, Watson et al. 1997, Gupta-Bansal and Brunden 1998, Cotman et al. 2000). The effects of GAGs on fibrillogenesis appear to be mediated by electrostatic interactions between $\mathrm{A} \beta$ and the highly sulfated chains of GAGs (McLaurin et al. 1999). These interactions take place at early stages during the process of fibril formation and result in the structural conversion of $\mathrm{A} \beta$ to $\beta$-sheet structures (Sipe
1992, McLaurin et al. 1999). The importance of sulfated groups in amyloid aggregation was highlighted by experiments showing a decrease in fibril formation in the presence of desulfated heparan sulfate (Castillo et al. 1999). Thus, it is believed that understanding the interactions between $\mathrm{A} \beta$ and sulfated GAGs may lead to effective inhibitors of amyloid aggregation (Fraser et al. 2001).

Apolipoprotein E (ApoE) isoforms appear to differentially influence $\mathrm{A} \beta$ aggregation and neurotoxicity, either facilitating or inhibiting aggregate formation in vitro (Wood et al. 1996, Moir et al. 1999, Drouet et al. 2001). Metal-induced aggregation of $\mathrm{A} \beta$ has been studied in the presence of purified ApoE2, ApoE3, and ApoE4 (used at the concentrations at which they are found in cerebrospinal fluid) (Moir et al. 1999). This study showed that metal-induced aggregation of $\mathrm{A} \beta$ was highest for both zinc and copper in the presence of ApoE4. A recent study has shown that ApoE2 and ApoE3, but not ApoE4, protect cortical neurons against neurotoxicity induced by $\mathrm{A} \beta$ (Drouet et al. 2001). Apolipopro- 
tein $\mathbf{J}$ (clusterin) is a multifunctional apolipoprotein made by cells in the brain and many other locations and is associated with aggregated $\mathrm{A} \beta$ in senile and diffuse plaques of Alzheimer's disease (AD). It has been shown that ApoJ partially blocks the aggregation of $\mathrm{A} \beta$ (Oda et al. 1995, Matsubara et al. 1996). In addition, when complexed to ApoJ, A $\beta$ is more resistant to proteolysis by trypsin and chymotrypsin (Matsubara et al. 1996). Apolipoprotein A-I (ApoA-I), a constituent of high-density lipoprotein complexes, has recently been shown to directly interact with the amyloid precursor protein (APP) and to inhibit $\mathrm{A} \beta$ aggregation and toxicity (Koldamova et al. 2001).

Activation of the complement pathway has been proposed as one of the mechanisms of neurodegeneration in Alzheimer's disease. This activation is a result of the binding of $\mathrm{C} 1 \mathrm{q}$ to $\mathrm{A} \beta$ (Webster et al. 1995, Head et al. 2001, Tacnet-Delorme et al. 2001). It has been shown that $\mathrm{C} 1 \mathrm{q}$ enhances $\mathrm{A} \beta$ aggregation at physiological concentrations, and that the kinetics of this enhancement are consistent with a nucleating interaction (Webster et al. 1995).

Acetylcholinesterase is an enzyme involved in the hydrolysis of the neurotransmitter acetylcholine and consistently co-localizes with amyloid deposits (Alvarez et al. 1997, Talesa 2001). In vitro, acetylcholinesterase promotes aggregation of $\mathrm{A} \beta$ by forming a complex with the growing fibrils (Alvarez et al. 1997). Recently, it has been shown that acetylcholinesterase interacts with $\mathrm{A} \beta$ via a hydrophobic domain close to the peripheral anionic binding site of the enzyme (De Ferrari et al. 2001). Basement membrane components, including entactin and laminin, also co-localize with senile plaques. Laminin inhibits $\mathrm{A} \beta$ fibril formation promoted by ApoE4 in vitro (Monji et al. 1998), and, more recently, entactin was also found to inhibit $\mathrm{A} \beta$ aggregation in vitro (Kiuchi et al. 2001).

Interactions between $\mathrm{A} \beta$ and phosphatidylinositol accelerate amyloid fibril formation, presumably through the structural conversion of $\beta$-amyloid from a random coil to $\beta$-sheet structure (Terzi et al. 1994, 1995, McLaurin and Chakrabartty 1996,
1997). By contrast, inositol stereoisomers (sugars involved in lipid biosynthesis, signal transduction and control of osmolarity) stabilize small $\mathrm{A} \beta$ aggregates, blocking the progress of fibril formation (McLaurin et al. 1998, 2000). Formation of a complex between $\mathrm{A} \beta$ and inositol significantly atennuates the toxicity of $\mathrm{A} \beta$ to neurons in culture (McLaurin et al. 2000). Inositol stereoisomers are phyisiological molecules that cross the blood-brain barrier, thus representing possible pharmacological tools in AD.

Gangliosides induce a distinct $\alpha$-helical $/ \beta$ sheet conformation of $\mathrm{A} \beta$ at neutral $\mathrm{pH}$ (McLaurin and Chakrabartty 1996). Subsequent work by the same group showed that the interaction of $\mathrm{A} \beta$ with glycolipids, such as gangliosides of the GM1 type, prevents amyloid fibril formation and that the sialic acid moiety of gangliosides is necessary for the induction of $\alpha$-helical structure (McLaurin et al. 1998, 2000).

Trimethylamine-N-oxide, a physiological osmolyte, and glycerol induce the conversion of $\mathrm{A} \beta$ from random coil to $\beta$-sheet structure, leading to the formation of tetrameric $\mathrm{A} \beta$ globular aggregates and early-stages protofibrils that are later transformed into mature fibrils (Yang et al. 1999).

Metals such as $\mathrm{Zn}^{2+}, \mathrm{Fe}^{3+}$ and $\mathrm{Cu}^{2+}$ are also associated with amyloid deposits found in AD patients (Lovell et al. 1998). The precise sources of these ions are not yet completely understood, but there is evidence indicating that they are released from metalloproteins under slightly acidic conditions during inflammatory responses (Brieland and Fantone 1991, Lamb and Leake 1994). A number of studies have shown that $\mathrm{Zn}^{2+}, \mathrm{Ni}^{2+}$ or $\mathrm{Cu}^{2+}$ induce fast amyloid aggregation in vitro and in vivo (Bush et al. 1994, Clements et al. 1996, Huang et al. 1997, Brown et al. 1997, Atwood et al. 1998). Aminoacid replacement studies have identified His13 as the metal ion ligand of $\mathrm{A} \beta$ (Liu et al. 1999). Replacement of His 13 by Arg inhibits the structural transition from random coil to $\beta$-sheet and fibrillogenesis (Liu et al. 1999). Recent studies have shown that $\mathrm{Cu}^{2+}$ chelators, such as trien- 
tine, penicilamine and bathophenantroline can be used to solubilize $\mathrm{A} \beta$ aggregates extracted in PBS buffer from AD brains (Cherny et al. 1999, 2000). These studies suggest that the combined properties of metal chelators and agents capable of dissolving $\mathrm{A} \beta$ aggregates can be complementary in the treatment of Alzheimer's disease (Cherny et al. 1999, 2000, Cuajungco et al. 2000).

\section{TARGETTING $\beta$-AMYLOID PRODUCTION AND AGGREGATION AS POSSIBLE THERAPEUTIC APPROACHES IN AD}

As noted above, the search for agents capable of blocking, decreasing or disrupting amyloid aggregation has become a focus of intense research interest. In this regard, a significant challenge consists in finding agents that interfere with amyloid aggregation and, at the same time, are non-toxic, capable of crossing the blood-brain barrier and stable against proteolytic degradation in plasma and cerebrospinal fluid. To date, several agents capable of interfering with $\beta$-amyloid aggregation have been characterized, including low molecular weight organic compounds, hormones, antibodies and peptides. Some of the properties, advantages and possible caveats of such agents are discussed below.

\subsection{Monoclonal Antibodies}

Early studies showed that immune complexes containing two monoclonal antibodies (6C6 and 10D5) raised against the $\mathrm{N}$-terminal region of $\mathrm{A} \beta$ disaggregated previously formed amyloid fibrils and protected neurons in culture from the toxic effects of A $\beta$ (Solomon et al. 1996, 1997). Further studies showed that the amino acid sequence EFRH, corresponding to residues 3-6 of the $\beta$-amyloid peptide, represents the epitope for monoclonal antibodies 6C6 and 10D5, acting as a regulatory site that controls the process of amyloid aggregation (Frenkel et al. 1998, 1999). More recently, it has been found that a new antibody, named $508 \mathrm{~F}$, directed at the same epitope prevents the neurotoxic effects of $\mathrm{A} \beta$ and disrupts amyloid fibrils in vitro (Frenkel et al. 2000).

\subsection{Peptides}

Based on their complementarities to specific $\mathrm{A} \beta$ sequences, two peptides with sequences RDLPFFDVPID and LPFFD have been designed (Soto et al. 1996). Due to the incorporation of proline residues in their sequences, these peptides exhibit low propensities to form $\beta$-sheet structures. Interestingly, such " $\beta$-sheet breaker peptides" were found to inhibit the fibrillogenesis of $\mathrm{A} \beta$ and to dissolve preformed fibrils (Soto et al. 1996, 1998). The LPFFD peptide also prevents the neurotoxicity of $\mathrm{A} \beta$ in primary neuronal cultures, reduces the in vivo deposition of $\mathrm{A} \beta$ in a cerebral model of amyloidosis in rats (Soto et al. 1998), and reduces the extension of IL-1 positive microglial cells surrounding the amyloid deposits (Sigurdsson et al. 2000). Interestingly, $\beta$-sheet breaker peptides have also been shown to reverse conformational changes of the prion protein involved in transmissible spongiform encephalopathies (Soto et al. 2000). Possible problems associated with the use of peptides in the treatment of diseases of the central nervous system are related to their rapid proteolytic degradation in the plasma and/or cerebrospinal fluid, and low permeability across the blood-brain barrier. In this regard, a recent study has shown that covalent incorporation of polyamines to an 11-amino acid long $\beta$-sheet breaker peptide leads to an increase in both the permeability across the blood-brain barrier and resistance to proteolytic degradation (Poduslo et al. 1999).

\subsection{HORMONES}

The pineal hormone, melatonin, is involved in the regulation of cyrcadian rythms. Melatonin levels are known to decrease in normal aging, and are specially low in Alzheimer's disease (Skene et al. 1990). Recent studies have shown that melatonin interacts with $\mathrm{A} \beta_{1-40}$ and $\mathrm{A} \beta_{1-42}$, inhibiting fibrillogenesis (Pappolla et al. 1998) and preventing cellular death in culture, oxidative damage and the increase in intracellular $\mathrm{Ca}^{2+}$ induced by $\mathrm{A} \beta$ (Pappolla et al. 1997, 2000). Additional studies have shown that 
melatonin protects platelet membranes from lipid peroxidation induced by $\mathrm{A} \beta$ (Daniels et al. 1998), and cells in culture from mitochondrial oxidative damage induced by $\mathrm{A} \beta$ (Pappolla et al. 1999). The indol derivative, 3-indol-propionic acid, which is structurally related to melatonin, also exhibits neuroprotective action against $\mathrm{A} \beta$ toxicity (Chyan et al. 1999 ) and a recent study has shown that melatonin reduces the secrection of interleukines 1 and 6 in mouse brain slices (Clapp-Lilly et al. 2001).

Possible biological effects of estrogen on neurotransmitter activity and neuronal development have been proposed (for a review, see Alonso-Solis et al. 1996). These studies suggest that estrogen (specially its prevalent form in human ovaries, estradiol) exihibits antioxidant properties and may affect relevant events in Alzheimer's disease (Behl et al. 1995, Kawas et al. 1997). In addition, estrogen has been shown to regulate APP processing, causing increased secretion of the non-amyloidogenic fragment $\operatorname{sAPP} \alpha$ and a concomitant decrease in $\beta$-amyloid peptide formation (Jaffe et al. 1994, Xu et al. 1998, Manthey et al. 2001). This effect appears to be mediated via the extracellular-regulated kinase 1 and 2 (ERK1/2) pathways (Manthey et al. 2001). Estrogen protects neurons in culture from the toxic effects of exogenously added $\mathrm{A} \beta$ (Gridley et al. 1997, Mook-Jung et al. 1997, Zhang et al. 2001) and protects neuronal cells from $\mathrm{A} \beta$-induced apoptotic cell death (Hosoda et al. 2001). A recent study has shown that estrogen enhances $\mathrm{A} \beta$ uptake in human cortical microglial cultures, suggesting an important role of estrogen in $\mathrm{A} \beta$ peptide clearance (Li et al. 2000). In line with this idea, another study has shown that testosterone also interferes with APP processing, leading to an enhancement of $\operatorname{sAPP} \alpha$ production and a reduction in $\mathrm{A} \beta$ levels in neurons in culture (Gouras et al. 2000). These results are in accordance with epidemiological studies that suggest that women that received estrogen replacement therapy in the post-menopausal phase are less suceptible to the development of Alzheimer's disease than women not receiving estrogen (Kawas et al. 1997, Seshadri et al. 2001). However, the protective role of estrogen in $\beta$-amyloid toxicity is still controversial, as other epidemiological studies have failed to identify a lower risk of developing Alzheimer's disease in women that received hormonal replacement therapy (Seshadri et al. 2001).

\subsection{Inhibition of $\mathrm{A} \beta$ Peptide Formation}

Current strategies to decrease or prevent $\beta$-amyloid peptide formation are based on the inhibition of $\gamma$ - and $\beta$-secretase activities or enhancement of $\alpha$ secretase activity. Since $\mathrm{A} \beta$ formation preceeds amyloid plaque formation and neuronal death, blocking its production may constitute an effective therapeutic approach in $\mathrm{AD}$.

Activation of $\alpha$-secretase, which forms the sAPP $\alpha$ fragment, may be used as a strategy to prevent APP processing by $\beta$ - and $\gamma$-secretases. In this regard, in vitro studies have shown that phosphatase inhibitors, protein kinase $\mathrm{C}$ activators and acetylcholinesterase inhibitors enhance APP clivage by $\alpha$ secretase, increasing the release of sAPP $\alpha$ (Gandy and Greengard 1994, da Cruz e Silva et al. 1995, Giacobini 1997). Nevertheless, it is believed that different proteases (including desintegrin, metalloproteases, TNF- $\alpha$, ADAM-17 and ADAM-10) contribute to the $\alpha$-secretase activity (Nunan and Small 2000). Thus, it seems dificult to specifically regulate, from the pharmacological point of view, this pathway of APP proteolysis.

$\beta$-secretase (BACE) has only recently been identified (Sinha et al. 1999, Vassar et al. 1999, Yan et al. 1999) and it remains unclear whether presenilins and nicastrin are required components for $\gamma$-secretase activity. Therefore, studies involving pharmacological inhibition of these enzymes have mainly been carried out in an indirect way, through the observation of the decrease in $\mathrm{A} \beta$ production in the presence of certain inhibitors (e.g., gelatinase A, bafilomicin A, calpain inhibitor, brefeldin and NH4Cl) (Asami-Odaka et al. 1995, Knops et al. 1995, Higaki et al. 1995, Citron et al. 1996).

Recent studies have identified new inhibitors of BACE, including the protease inhibitor MG132 and calcium ionofore A23187 (Steinhilb et al. 2000, 
Sennvik et al. 2001). In addition, the proteolytic domain structure of $\beta$-secretase complexed to an octapeptide inhibitor was recently solved (Hong et al. 2000). BACE has structural homology to the HIV protease, and, thus, many inhibitors of the latter can modulate BACE activity (Nunan and Small 2000). Transgenic mice over-expressing APP and deficient in BACE expression are viable, present normal phenotype and a decrease in $\mathrm{A} \beta$ peptide production (Luo et al. 2001), suggesting that in vivo inhibition of BACE may be therapeutically valuable. However, it is important to note that, in humans, BACE can have other physiological substrates in addition to APP, and may be involved in important biological functions that could be affected by the use of inhibitors (Nunan and Small 2000).

Recent studies have also identified inhibitors of $\gamma$-secretase activity, including difluoroketone, difluoro alcohol peptideomimetics, a bromoacetamide derivative, and a benzofenone analog (Seiffert et al. 2000, Moore et al. 2000). Of considerable interest, a very recent study has shown, for the first time, the in vivo inhibition of $\gamma$-secretase activity through the oral administration of the compound $\mathrm{N}$-[N-[3,5-difluorophenacetyl) -L-alanil]- Sphenilglycin t- butyl ester to transgenic mice overexpressing human APP, resulting in the reduction of $\mathrm{A} \beta$ levels in the brain (Dovey et al. 2001). However, as in the case of BACE, it is not clear whether the inhibition of $\gamma$-secretase may become a realistic therapy for Alzheimer's disease, as these enzymes can play other important physiological roles in addition to APP processing and $\beta$-amyloid peptide production, and, thus, the inhibition of secretases could lead to important cell disfunctions.

\subsection{Clearance of $\mathrm{A} \beta$}

The correct balance between production and catabolism of $\mathrm{A} \beta$ appears directly related to Alzheimer's disease, as the over-production of $\beta$-amyloid peptide is not followed by a parallel increase in its clearance in both familiar and sporadic forms of AD (Scheuner et al. 1996, Hardy 1997, Selkoe 1998, Price et al. 1998). Furthermore, recent observations suggest that reduction of $\mathrm{A} \beta$ catabolism leads to brain accumulation of this peptide, triggering initial processes of the disease (Iwata et al. 2000). In this regard, an interesting therapeutic approach to $\mathrm{AD}$ might consist of increasing the degradation and clearance of $\mathrm{A} \beta$. However, knowledge of the mechanisms involved in $\mathrm{A} \beta$ degradation and clearance is still limited. Early studies showed that microglial cells uptake $\mathrm{A} \beta$ in vitro through receptor-mediated mechanisms (Shaffer et al. 1995, Paresce et al. 1996), and that this process can be slowed down in the presence of proteoglycans (Shaffer et al. 1995). Recently, it has been shown that the uptake of $\mathrm{A} \beta$ by microglia is induced by a chaperonin, BiP/GRP-78 (Kakimura et al. 2001). In addition, it has been shown that inhibition of $\mathrm{A} \beta$ fibrillogenesis by 4'-iodo- 4'-deoxydoxorubicin (IDOX) facilitates clearance of the peptide (Merlini et al. 1995).

The insulin degrading enzyme (insulysin) appears to play an important role in regulating extracellular $\beta$-amyloid peptide levels (Vekrellis et al. 2000), by hydrolyzing $\mathrm{A} \beta$ into various fragments that are not neurotoxic (Vekrellis et al. 2000, Mukherjee et al. 2000, Chesneau et al. 2000). $\alpha_{2}$ macroglobulin is also known to enhance $\mathrm{A} \beta$ clearance via interaction with the LDL receptor related protein (Qiu et al. 1999, Lauer et al. 2001). On the other hand, serine protease inhibitors, such as $\alpha_{1}$ antichymotrypsin, inhibit the clearance of $\mathrm{A} \beta$ both in vitro and in vivo (Abraham et al. 2000), increasing plaque formation in transgenic mice (Abraham et al. 2000, Mucke et al. 2000).

Neprilysin, a neutral endopeptidase, has recently been identified as responsible for the major $\mathrm{A} \beta_{1-42}$ catabolic pathway in brain parenchyma (Iwata et al. 2000). Infusion of thiorphan, a neprilysin inhibitor, in rat brains causes extracellular amyloid deposition of endogenous $\mathrm{A} \beta$ (Iwata et al. 2000, Shirotani et al. 2001). Neprilysin deficiency resulted in defects both in the degradation of exogenously administered $\mathrm{A} \beta$ and in the metabolic suppression of endogenous $\mathrm{A} \beta$ in a gene dose-dependent manner (Iwata et al. 2000) and an inverse association between vulnerability to $\mathrm{A} \beta$ de- 
position and immunohistochemical localization of neprilysin in human cerebral cortex has been reported (Akiyama et al. 2000).

\subsection{Immunization with A $\beta$ Peptide}

Studies using transgenic mice over-expressing human APP have shown that immunization with $\mathrm{A} \beta$ peptide leads to a significant reduction in brain amyloid plaques (Schenk et al. 1999). In a subsequent study, antibodies raised against the $\beta$-amyloid peptide were peripherally administered (i.e., in a passive immunization transfer protocol), and were found to gain access to the central nervous system and to reduce amyloid plaque burden in transgenic mice (Games et al. 2000). Passive immunization also decreased astrocytosis and brain inflammatory response induced by $\mathrm{A} \beta$ peptide (Bard et al. 2000). Further studies by other groups confirmed that immunization of transgenic mice with $\mathrm{A} \beta$ reduced the fibrillar deposition of $\beta$-amyloid peptide (Sigurdsson et al. 2001) and protected against cognitive disfunction (Janus et al. 2000, Morgan et al. 2000). In accordance with these studies, direct in vivo observations in transgenic mice brains through the use of multi-photon fluorescence microscopy have recently shown that immunization with $\mathrm{A} \beta$ leads to the clearance of amyloid plaques (Bacskai et al. 2001, DeMattos et al. 2001).

It is believed that immunization can modulate the metabolism of $\mathrm{A} \beta$ through distinct mechanisms, including its destruction by microglial fagocytosis (Bard et al. 2000) and redistribution of $\mathrm{A} \beta$ from neuritic plaques to diffuse plaques (Janus et al. 2000). These distinct effects can reflect differences in antigen presentation, or "lineage-specific" immune response (Schenk et al. 1999, Bard et al. 2000, Janus et al. 2000). If indeed this is found to be the case, such differences may complicate the use of active immunization in humans (St.George-Hyslop and Westaway 1999, Janus et al. 2000). Furthermore, it is important to note that despite the important reduction of plaque formation and prevention of cognitive decline, no study so far has been able to demonstrate the complete reversion of amyloid plaque formation by immunization with $\mathrm{A} \beta$ (Janus et al. 2000).

\subsection{Small Molecule Inhibitors of A $\beta$ Aggregation: Nitrophenols}

Another approach that has been pursued consists in the search for anti-amyloidogenic compounds capable of preventing the neurotoxicity of $\mathrm{A} \beta$. In the lack of detailed molecular structures of either soluble or fibrillar $\mathrm{A} \beta$ (which precludes a structure-based drug design approach), one strategy to identify potential anti-amyloidogenic compounds has relied on an investigation of the stability of amyloid fibrils (De Felice et al. 2001, Ferreira and De Felice 2001). These studies have indicated that a significant contribution to the stability of $\mathrm{A} \beta$ fibrils comes from entropy-driven hydrophobic interactions, leading to the hypothesis that low molecular weight hydrophobic compounds could be effective in destabilizing and disaggregating amyloid fibrils.

After examining a number of moderately hydrophobic compounds, we found that 2,4-dinitrophenol (DNP) and 3-nitrophenol (NP) prevent amyloid aggregation in vitro and cause the disassembly of pre-aggregated fibrils (De Felice et al. 2001). Of greater interest, nitrophenols block the neurotoxicity of $\mathrm{A} \beta$ to rat hippocampal neurons in primary culture, and cause a marked reduction in the area occupied by amyloid deposits in a rat model system of amyloidosis (De Felice et al. 2001). DNP is known for its toxic effects related to mitochondrial uncoupling, which raises concerns about the possible therapeutic applications of this compound. Interestingly, however, at the low concentrations employed to destabilize amyloid aggregates, no toxic effects of DNP were detected in either neuronal cultures or in brains slices of animals that received intra-cerebral injections of DNP (De Felice et al. 2001). Thus, since at present there is no effective treatment available for amyloidoses, including AD, Type II diabetes and prion-related spongiform encephalopathies, we have proposed that nitrophenols and their derivatives should be explored as possible drug candidates or lead compounds for the develop- 
ment of drugs to prevent amyloid aggregation and neurotoxicity in Alzheimer's disease.

\section{CONCLUSIONS}

Despite intense research efforts into elucidating the molecular and cellular basis of Alzheimer's disease, no effective treatments are yet available to stop it or to prevent its development. As reviewed above, several different approaches addressing distinct aspects of the disease are being pursued in an attempt to develop effetive therapies. Given the multifactorial nature of this disease (Selkoe 1999), it seems unlikely that a single therapeutic target may lead to an effective treatment for AD. Instead, the simultaneous employment of distinct strategies aiming at decreasing $\mathrm{A} \beta$ production (through manipulation of the activities of secretases), stimulation of the physiological mechanisms of clearance of the peptide and inhibition of amyloid aggregation may eventually constitute an effective approach to the prevention and treatment of $\mathrm{AD}$.

\section{ACKNOWLEDGMENTS}

Work in the laboratory of the authors has been supported over the years by grants from Howard Hughes Medical Institute, John Simon Guggenheim Memorial Foundation, Financiadora de Estudos e Projetos, Fundação de Amparo à Pesquisa do Estado do Rio de Janeiro, Conselho Nacional de Desenvolvimento Científico e Tecnológico and Programa de Apoio ao Desenvolvimento Científico e Tecnológico. STF is a Howard Hughes Medical Institute International Research Scholar.

\section{RESUMO}

Os mecanismos biológicos envolvidos na neuropatologia da doença de Alzheimer (DA) são complexos, já que vários fatores contribuem para o desenvolvimento da doença. Portanto, não é surpreendente que diferentes abordagens terapêuticas possíveis envolvendo aspectos distintos da doença estejam sendo investigados atualmente. Estas abordagens incluem a prevenção da agregação e/ou deposição amilóide, a prevenção da degeneração neuronal e o aumento do nível de neurotransmissores. Nesta revisão, nós discutimos possíveis papéis de moduladores endógenos da agregação de peptídeo $\mathrm{A} \beta$ na fisiopatologia da DA e algumas estratéfias atualmente sob consideração para interferir com os níveis do peptídeo $\mathrm{A} \beta$, sua agregação e neurotoxicidade.

Palavras-chave: doença de Alzheimer, peptídeo $\mathrm{A} \beta$, agregação, neurotoxicidade, moduladores fisiopatológicos.

\section{REFERENCES}

Abraham CR, Selkoe DJ and Potter H. 1988. Immunochemical identification of the serine protease inhibitor alpha 1-antichymotrypsin in the brain amyloid deposits of Alzheimer's disease. Cell 52 (4): 487-501.

Abraham CR, McGraw WT, Slot F and Yamin R. 2000. Alpha 1-antichymotrypsin inhibits A beta degradation in vitro and in vivo. Ann N Y Acad Sci 920: 245-248.

Akiyama H, Barger S, Barnum S, Bradt B, Bauer J, Cole GM, Cooper NR, Eikelenboom P, EMmerling M, Fiebich BL, Finch CE, Frautschy S, Griffin WS, Hampel H, Hull M, Landreth G, Lue L, Mrak R, Mackenzie IR, McGeer PL, O’Banion MK, Pachter J, Pasinetti G, PlataSalaman C, Rogers J, Rydel R, Shen Y, Streit W, Strohmeyer R, Tooyoma I, Van Muiswinkel FL, Veerhuis R, Walker D, Webster S, WegrzyNIAK B, WENK G AND Wyss-CORAY T. 2000. Inflammation and Alzheimer's disease. Neurobiol Aging 21 (3): 383-421.

Alonso-Solis R, Abreu P, Lopez-Coviella I, HernandeZ G, Fajardo N, Hernandez-Diaz F, DiazCruz A and Hernandez A. 1996. Gonadal steroid modulation of neuroendocrine transduction: a transynaptic view. Cell Mol Neurobiol 16 (3): 357-382.

Alvarez A, Opazo C, Alarcon R, Garrido J and IneSTROSA NC. 1997. Acetylcholinesterase promotes the aggregation of amyloid-beta-peptide fragments by forming a complex with the growing fibrils. J Mol Biol 272 (3): 348-361.

Asami-Odaka A, Ishibashi Y, Kikuchi T, Kitada C AND SUZUKI N. 1995. Long amyloid beta-protein secreted from wild-type human neuroblastoma IMR- 
32 cells. Biochemistry 34 (32): 10272-10278.

Atwood CS, Moir RD, Huang X, Scarpa RC, BacArra NM, ROMANO DM, HARTSHORN MA, TANZI RE AND Bush AI. 1998. Dramatic aggregation of Alzheimer A beta by $\mathrm{Cu}(\mathrm{II})$ is induced by conditions representing physiological acidosis. J Biol Chem 273 (21): 12817-12826.

Bacskai BJ, Kajdasz St, Christie RH, Carter C, Games D, Seubert P, Schenk D and Hyman BT. 2001. Imaging of amyloid-beta deposits in brains of living mice permits direct observation of clearance of plaques with immunotherapy. Nat Med 7 (3): 369372.

Bard F, Cannon C, Barbour R, Burke RL, Games D, Grajeda H, Guido T, Hu K, Huang J, JohnsonWood K, Khan K, Kholodenko D, LeE M, Lieberburg I, Motter R, Nguyen M, Soriano F, VasQuez N, Weiss K, Welch B, Seubert P, Schenk D AND Yednock T. 2000. Peripherally administered antibodies against amyloid beta-peptide enter the central nervous system and reduce pathology in a mouse model of Alzheimer disease. Nat Med 6 (8): 916-919.

Behl C, Widmann M, Trapp $\mathrm{T}$ and Holsboer F. 1995. 17-beta estradiol protects neurons from oxidative stress-induced cell death in vitro. Biochem Biophys Res Commun 216 (2): 473-482.

Bohrmann B, Tuernberg L, Kuner P, Poli S, LevetTrafit B, Naslund J, Richards G, Huber W, DoBELI H AND NordSTEDT C. 1999. Endogenous proteins controlling amyloid beta-peptide polymerization. Possible implications for beta-amyloid formation in the central nervous system and in peripheral tissues. J Biol Chem 274: 15990-15995.

Brieland JK and Fantone JC. 1991. Ferrous iron release from transferrin by human neutrophil-derived superoxide anion: effect of $\mathrm{pH}$ and iron saturation. Arch Biochem Biophys 284 (1): 78-83.

Brown AM, Tummolo DM, Rhodes KJ, Hofmann JR, JACOBSEn JS AND SonNEnBERG-REINES J. 1997. Selective aggregation of endogenous beta-amyloid peptide and soluble amyloid precursor protein in cerebrospinal fluid by zinc. J Neurochem 69 (3): 1204-1212.

Brunden KR, Richter-CoOK NJ, Chaturvedi N AND FREDERICKSON RC. 1993. pH-dependent binding of synthetic beta-amyloid peptides to glycosaminoglycans. J Neurochem. 61 (6): 2147-2154.

Buee L, Ding W, Anderson JP, Narindrasorasak S, Kisilevsky R, Boyle NJ, Robakis NK, Delacourte A, GreenbergB and Fillit HM. 1993a. Binding of vascular heparan sulfate proteoglycan to Alzheimer's amyloid precursor protein is mediated in part by the $\mathrm{N}$-terminal region of A4 peptide. Brain Res 627 (2): 199-204.

Buee L, Ding W, Delacourte A and Fillit H. 1993b. Binding of secreted human neuroblastoma proteoglycans to the Alzheimer's amyloid A4 peptide. Brain Res 601 (1-2): 154-163.

Bush AI, Pettingell WH, Multhaup G, Paradis MD, Vonsattel JP, Gusella JF, Beyreuther K, MasTERS CL AND TANZI RE. 1994. Rapid induction of Alzheimer A beta amyloid formation by zinc. Science 265 (5177): 1464-1467.

Castillo GM, Ngo C, Cummings J, Wight TN and SNOw AD. 1997. Perlecan binds to the beta-amyloid proteins (A beta) of Alzheimer's disease, accelerates A beta fibril formation, and maintains $\mathrm{A}$ beta fibril stability. J Neurochem 69 (6): 2452-2465.

Castillo GM, Lukito W, Wight TN and Snow AD. 1999. The sulfate moieties of glycosaminoglycans are critical for the enhancement of beta-amyloid protein fibril formation. J Neurochem 72 (4): 16811687.

Cherny RA, Legg JT, McLean CA, Fairlie DP, Huang X, Atwood CS, Beyreuther K, Tanzi RE, MasTERS CL AND Bush AI. 1999. Aqueous dissolution of Alzheimer's disease Abeta amyloid deposits by biometal depletion. J Biol Chem 274 (33): 2322323228.

Cherny RA, Barnham KJ, Lynch T, Volitakis I, Li QX, Mclean CA, Multhaup G, Beyreuther K, TAnZi RE, Masters CL and Bush AI. 2000. Chelation and intercalation: complementary properties in a compound for the treatment of Alzheimer's disease. J Struct Biol 130 (2-3): 209-216.

Chesneau V, Vekrellis K, Rosner MR and Selkoe DJ. 2000. Purified recombinant insulin-degrading enzyme degrades amyloid beta-protein but does not promote its oligomerization. Biochem J 351 (2): 509-516

Chyan YJ, Poeggeler B, Omar RA, Chain DG, Fran- 
Gione B, Ghiso J and Pappolla MA. 1999. Potent neuroprotective properties against the Alzheimer beta-amyloid by an endogenous melatonin-related indole structure, indole-3-propionic acid. J Biol Chem 274 (31): 21937-21942.

Citron M, Diehl TS, Capell A, Haass C, Teplow DB AND Selkoe DJ. 1996. Inhibition of amyloid beta-protein production in neural cells by the serine protease inhibitor AEBSF. Neuron 17 (1): 171-179.

Clapp-Lilly KL, Smith MA, Perry B and Duffy LK. 2001. Melatonin reduces interleukin secretion in amyloid-beta stressed mouse brain slices. Chem Biol Interact 134 (1): 101-107.

Clements A, Allsop D, Walsh DM and Williams CH. 1996. Aggregation and metal-binding properties of mutant forms of the amyloid A beta peptide of Alzheimer's disease. J Neurochem 66 (2): 740-747.

Cotman SL, Halfter W and Cole GJ. 2000. Agrin binds to beta-amyloid (Abeta), accelerates abeta fibril formation, and is localized to Abeta deposits in Alzheimer's disease brain. Mol Cell Neurosci 15 (2): 183-198.

Cuajungco MP, Faget KY, Huang X, Tanzi RE and Bush AI. 2000. Metal chelation as a potential therapy for Alzheimer's disease. Ann N Y Acad Sci 920: 292-304.

da Cruz e Silva EF, da Cruz e Silva OA, Zaia CT AND GREENGARD P. 1995. Inhibition of protein phosphatase 1 stimulates secretion of Alzheimer amyloid precursor protein. Mol Med 1 (5): 535-541.

Daniels WM, van Rensburg SJ, van Zyl JM and TaLJAARD JJ. 1998. Melatonin prevents beta-amyloidinduced lipid peroxidation. J Pineal Res 24 (2): 7882.

De Felice FG, Houzel JC, Garcia-Abreu J, Louzada PR Jr, Afonso RC, Meirelles MN, Lent R, Neto VM AND FERREIRA ST. 2001. Inhibition of Alzheimer's disease beta-amyloid aggregation, neurotoxicity, and in vivo deposition by nitrophenols: implications for Alzheimer's therapy. FASEB J 15 (7): 1297-1299.

De Ferrari GV, Canales MA, Shin I, Weiner LM, Silman I AND Inestrosa NC. 2001. A structural motif of acetylcholinesterase that promotes amyloid beta-peptide fibril formation. Biochemistry 40 (35): 10447-10457.
Demattos RB, Bales KR, Cummins DJ, Dodart JC, Paul SM and Holtzman DM. 2001. Peripheral anti-A beta antibody alters CNS and plasma A beta clearance and decreases brain A beta burden in a mouse model of Alzheimer's disease. Proc Natl Acad Sci USA 98 (15): 8850-8855.

DeWitt DA, Silver J, Canning DR and Perry G. 1993. Chondroitin sulfate proteoglycans are associated with the lesions of Alzheimer's disease. Exp Neurol 121 (2): 149-152.

Dovey HF, John V, Anderson JP, Chen LZ, de SAInT Andrieu PD, Fang LY, Freedman SB, Folmer B, Goldbach E, Holsztynska EJ, Hu KL, JohnsonWood KL, Kennedy SL, Kholodenko D, Knops JE, LATimer LH, LeE M, Liao Z, Lieberburg IM, Motter RN, Mutter LC, Nietz J, Quinn KP, SACChi KL, Seubert PA, Shopp GM, Thorsett ED, Tung JS, Wu J, Yang S, Yin CT, Schenk DB, May PC, Altstiel LD, Bender MH, Boggs LN, Britton TC, Clemens JC, Czilli DL, DieckmanMcGinty DK, Droste JJ, Fuson KS, Gitter BD, Hyslop PA, Johnstone EM, Li WY, Little SP, Mabry TE, Miller FD, Ni B, Nissen JS, Porter WJ, Potts BD, Reel JK, Stephenson D, Su Y, Shipley LA, Whitesitt CA, Yin T And Audia JE. 2001. Functional gamma-secretase inhibitors reduce beta-amyloid peptide levels in brain. J Neurochem 76 (1): 173-181.

Drouet B, Fifre A, Pincon-Raymond M, VandeKerckhove J, Rosseneu M, Gueant JL, ChamBAZ J AND Pillot T. 2001. ApoE protects cortical neurones against neurotoxicity induced by the nonfibrillar C-terminal domain of the amyloid-beta peptide. J Neurochem 76 (1): 117-127.

Du Y, Bales KR, Dodel RC, Liu X, GlinN MA, Horn JW, Little SP ANd PAul SM. 1998. Alpha2-macroglobulin attenuates beta-amyloid peptide 1-40 formation and associated neurotoxicity of cultured fetal rat cortical neurons. J Neurochem 70 (3): 1182-1188.

ERIKSSON S, JANCIAUSKIENE S AND LANNFELT L. 1995. Alpha 1-antichymotrypsin regulates Alzheimer betaamyloid peptide fibril formation. Proc Natl Acad Sci USA 92 (6): 2313-2317.

Evans KC, Berger EP, Cho CG, Weisgraber KH And LANSBURY PT JR. 1995. Apolipoprotein E is a kinetic but not a thermodynamic inhibitor of amyloid forma- 
tion: implications for the pathogenesis and treatment of Alzheimer disease. Proc Natl Acad Sci USA 92 (3): 763-767.

Ferreira ST and De Felice FG. 2001. Protein dynamics, folding and misfolding: from basic physical chemistry to human conformational diseases. FEBS Lett. 498:129-134.

Fraser PE, Nguyen JT, Surewicz WK ANd Kirschner DA. 1991. pH-dependent structural transitions of Alzheimer amyloid peptides. Biophys J 60 (5): 11901201.

Fraser PE, Nguyen JT, Chin DT AND Kirschner DA. 1992. Effects of sulfate ions on Alzheimer beta/A4 peptide assemblies: implications for amyloid fibril-proteoglycan interactions. J Neurochem 59 (4): 1531-1540.

Fraser Pe, Nguyen JT, Mclachlan DR, AbraHAM CR AND KIRSCHNER DA. 1993. Alpha 1antichymotrypsin binding to Alzheimer A beta peptides is sequence specific and induces fibril disaggregation in vitro. J Neurochem 61 (1): 298-305.

Fraser PE, Darabie AA and Mclaurin JA. 2001. Amyloid-beta interactions with chondroitin sulfatederived monosaccharides and disaccharides. Implications for drug development. J Biol Chem 276 (9): 6412-6419.

Frenkel D, Balass M and Solomon B. 1998. Nterminal EFRH sequence of Alzheimer's betaamyloid peptide represents the epitope of its antiaggregating antibodies. J Neuroimmunol 88 (1-2): 85-90.

Frenkel D, Balass M, Katchalski-Katzir E AND Solomon B. 1999. High affinity binding of monoclonal antibodies to the sequential epitope EFRH of beta-amyloid peptide is essential for modulation of fibrillar aggregation. J Neuroimmunol 95 (1-2): 136-142.

Frenkel D, Solomon B and Benhar I. 2000. Modulation of Alzheimer's beta-amyloid neurotoxicity by site-directed single-chain antibody. J Neuroimmunol 106 (1-2): 23-31.

Games D, Bard F, Grajeda H, Guido T, Khan K, SoRIANO F, VASQUEZ N, WeHNER N, JOHNSON-WoOD K, Yednock T, Seubert P And Schenk D. 2000. Prevention and reduction of AD-type pathology in PDAPP mice immunized with A beta 1-42. Ann N Y
Acad Sci 920: 274-284.

Gandy Se and Greengard P. 1994. Processing of Alzheimer A beta-amyloid precursor protein: cell biology, regulation, and role in Alzheimer disease. Int Rev Neurobiol 36: 29-50.

Geula C, Wu CK, Saroff D, Lorenzo A, Yuan M and YANKNER BA. 1998. Aging renders the brain vulnerable to amyloid beta-protein neurotoxicity. Nat Med 4 (7): 827-831.

Giacobini E. 1997. From molecular structure to Alzheimer therapy. Jpn J Pharmacol 74 (3): 225-241.

Glenner GG AND Wong CW. 1984. Alzheimer's disease: initial report of the purification and characterization of a novel cerebrovascular amyloid protein. Biochem Biophys Res Commun 120 (3): 885-890.

Gouras GK, Xu H, Gross RS, Greenfield JP, Hai B, WANG R and GReEngard P. 2000. Testosterone reduces neuronal secretion of Alzheimer's betaamyloid peptides. Proc Natl Acad Sci USA 97 (3): 1202-1205.

Gridley KE, Green PS and SimpKins JW. 1997. Low concentrations of estradiol reduce beta-amyloid (25$35)$-induced toxicity, lipid peroxidation and glucose utilization in human SK-N-SH neuroblastoma cells. Brain Res 778 (1): 158-165.

Gupta-Bansal R and Brunden KR. 1998. Congo red inhibits proteoglycan and serum amyloid $\mathrm{P}$ binding to amyloid beta fibrils. J Neurochem 70 (1): 292-298.

HaAss C and De Strooper B. 1999. The presenilins in Alzheimer's disease-proteolysis holds the key. Science 286 (5441): 916-919.

HARDy J. 1997. Amyloid, the presenilins and Alzheimer's disease. Trends Neurosci 20 (4): 154-159.

Head E, Azizeh By, Lott IT, Tenner AJ, Cotman CW AND CribBs DH. 2001. Complement association with neurons and beta-amyloid deposition in the brains of aged individuals with Down Syndrome. Neurobiol Dis 8 (2): 252-265.

Higaki J, Quon D, Zhong Z and Cordell B. 1995. Inhibition of beta-amyloid formation identifies proteolytic precursors and subcellular site of catabolism. Neuron 14 (3): 651-659.

Hong L, Koelsch G, Lin X, Wu S, Terzyan S, Ghosh AK, Zhang XC and TANG J. 2000. Structure of the protease domain of memapsin 2 (beta-secretase) 
complexed with inhibitor. Science 290 (5489): 150-153.

Hosoda T, NaKajima H and Honjo H. 2001. Estrogen protects neuronal cells from amyloid beta-induced apoptotic cell death. Neuroreport 12 (9): 1965-1970.

Huang X, Atwood CS, Moir RD, Hartshorn MA, Vonsattel JP, TANZI RE AND Bush AI. 1997. Zincinduced Alzheimer's Abeta1-40 aggregation is mediated by conformational factors. J Biol Chem 272 (42): 26464-26470.

Hughes SR, Khorkova O, Goyal S, Knaeblein J, Heroux J, Riedel NG and Sahasrabudhe S. 1998. Alpha2-macroglobulin associates with beta-amyloid peptide and prevents fibril formation. Proc Natl Acad Sci USA 95 (6): 3275-3280.

InOUye H, Fraser PE AND Kirschner DA. 1993. Structure of beta-crystallite assemblies formed by Alzheimer beta-amyloid protein analogues: analysis by $\mathrm{x}$ ray diffraction. Biophys J 64 (2): 502-519.

Iwata $\mathrm{N}$, Tsubuki $\mathrm{S}$, Takaki $\mathrm{Y}$, Watanabe $\mathrm{K}$, Sekiguchi M, Hosoki E, Kawashima-Morishima M, Lee HJ, Hama E, Sekine-Aizawa Y and Saido TC. 2000. Identification of the major Abeta1-42degrading catabolic pathway in brain parenchyma: suppression leads to biochemical and pathological deposition. Nat Med 6 (2): 143-150.

JafFe AB, Toran-Allerand CD, Greengard P AND GANDY SE. 1994. Estrogen regulates metabolism of Alzheimer amyloid beta precursor protein. J Biol Chem 269 (18): 13065-13068.

JanCiauskiene S, ERIKSSON S AND Wright HT. 1996. A specific structural interaction of Alzheimer's peptide A beta 1-42 with alpha 1-antichymotrypsin. Nat Struct Biol 3 (8): 668-671.

Janciauskiene S, Rubin H, Lukacs CM ANd Wright HT. 1998. Alzheimer's peptide Abeta1-42 binds to two beta-sheets of alpha1-antichymotrypsin and transforms it from inhibitor to substrate. J Biol Chem 273 (43): 28360-28364

Janus C, Pearson J, McLaurin J, Mathews PM, Jiang Y, Schmidt SD, Chishti MA, HoRne P, Heslin D, French J, Mount HT, Nixon RA, Mercken M, Bergeron C, Fraser PE, St George-Hyslop P AND Westaway D. 2000. A beta peptide immunization reduces behavioural impairment and plaques in a model of Alzheimer's disease. Nature 408 (6815):
979-982.

Kakimura J, Kitamura Y, Taniguchi T, Shimohama S AND Gebicke-Haerter PJ. 2001. Bip/GRP78induced production of cytokines and uptake of amyloid-beta(1-42) peptide in microglia. Biochem Biophys Res Commun 281 (1): 6-10.

Kang J, Lemaire HG, Unterbeck A, Salbaum JM, Masters CL, GrzeschiK KH, Multhaup G, Beyreuther K and Muller-Hill B. 1987. The precursor of Alzheimer's disease amyloid A4 protein resembles a cell surface receptor. Nature 325: 733 736.

Kawas C, Resnick S, Morrison A, Brookmeyer R, Corrada M, Zonderman A, Bacal C, Lingle DD AND Metter E. 1997. A prospective study of estrogen replacement therapy and the risk of developing Alzheimer's disease: the Baltimore Longitudinal Study of Aging. Neurology 48 (6): 1517-1521.

Kiuchi Y, Isobe Y and Fukushima K. 2001. Entactininduced inhibition of human amyloid beta-protein fibril formation in vitro. Neurosci Lett 305 (2): 119122.

Knops J, Suomensaari S, Lee M, McConlogue L, Seubert P and Sinha S. 1995. Cell-type and amyloid precursor protein-type specific inhibition of $A$ beta release by bafilomycin A1, a selective inhibitor of vacuolar ATPases. J Biol Chem 270 (6): 24192422.

Koldamova RP, LeFterov IM, LeFterova MI AND LAzo JS. 2001. Apolipoprotein A-I directly interacts with amyloid precursor protein and inhibits A beta aggregation and toxicity. Biochemistry 40 (12): 3553-3560.

LAMB DJ AND LEAKE DS. 1994. Iron released from transferrin at acidic $\mathrm{pH}$ can catalyse the oxidation of low density lipoprotein. FEBS Lett 352 (1): 15-18.

Lauer D, Reichenbach A and Birkenmeier G. 2001. Alpha 2 - macroglobulin-mediated degradation of amyloid beta 1-42: a mechanism to enhance amyloid beta catabolism. Exp Neurol 167 (2): 385-392.

Levy E, Carman MD, Fernandez-Madrid IJ, Power MD, Lieberburg I, VAN Duinen SG, Bots GT, LuyendiJK W and Frangione B. 1990. Mutation of the Alzheimer's disease amyloid gene in hereditary cerebral hemorrhage, Dutch type. Science 248 (4959): 1124-1126. 
Li R, Sheny, Yang LB, Lue LF, Finch C and Rogers J. 2000. Estrogen enhances uptake of amyloid betaprotein by microglia derived from the human cortex. J Neurochem 75 (4): 1447-1454.

Lin X, Koelsch G, Wu S, Downs D, Dashti A And TANG J. 2000. Human aspartic protease memapsin 2 cleaves the beta-secretase site of beta-amyloid precursor protein. Proc Natl Acad Sci USA 97 (4): 14561460.

Liu ST, Howlett G and Barrow CJ. 1999. Histidine13 is a crucial residue in the zinc ion-induced aggregation of the A beta peptide of Alzheimer's disease. Biochemistry 38 (29): 9373-9378.

LoRenzo A AND YANKNer BA. 1994. Beta-amyloid neurotoxicity requires fibril formation and is inhibited by congo red. Proc Natl Acad Sci USA 91 (25): 12243-12247.

Lovell MA, Robertson JD, Teesdale WJ, Campbell JL AND MARKeSbery WR. 1998. Copper, iron and zinc in Alzheimer's disease senile plaques. J Neurol Sci 158 (1): 47-52.

Lukacs CM and Christianson DW. 1996. Is the binding of beta-amyloid protein to antichymotrypsin in Alzheimer plaques mediated by a beta-strand insertion? Proteins 25 (4): 420-424.

Luo Y, Bolon B, Kahn S, Bennett BD, Babu-Khan S, Denis P, Fan W, Kha H, Zhang J, Gong Y, MarTin L, Louis JC, YaN Q, Richards WG, Citron M AND VASSAR R. 2001. Mice deficient in BACE1, the Alzheimer's beta-secretase, have normal phenotype and abolished beta-amyloid generation. Nat Neurosci 4 (3): 231-242.

Ma J, Yee A, Brewer HB Jr, Das S and Potter H. 1994. Amyloid-associated proteins alpha 1-antichymotrypsin and apolipoprotein E promote assembly of Alzheimer beta-protein into filaments. Nature 372 (6501): 92-94.

Manthey D, Heck S, Engert S and Behl C. 2001. Estrogen induces a rapid secretion of amyloid beta precursor protein via the mitogen-activated protein kinase pathway. Eur J Biochem 268 (15): 42854291.

Masters CL, Multhaup G, Simms G, Pottgiesser J, Martins RN ANd Beyreuther K. 1985. Neuronal origin of a cerebral amyloid: neurofibrillary tangles of Alzheimer's disease contain the same protein as the amyloid of plaque cores and blood vessels. EMBO J 4 (11): 2757-2763.

Matsubara E, Soto C, Governale S, Frangione B AND GHiso J. 1996. Apolipoprotein J and Alzheimer's amyloid beta solubility. Biochem J 316 (2): 671-679.

McLaurin J and Chakrabartty A. 1996. Membrane disruption by Alzheimer beta-amyloid peptides mediated through specific binding to either phospholipids or gangliosides. Implications for neurotoxicity. J Biol Chem 271: 26482-26489.

McLaurin J And Chakrabartty A. 1997. Characterization of the interactions of Alzheimer beta-amyloid peptides with phospholipid membranes. Eur J Biochem 245 (2): 355-363.

Mclaurin J, Franklin T, Chakrabartty A AND Fraser PE. 1998. Phosphatidylinositol and inositol involvement in Alzheimer amyloid-beta fibril growth and arrest. J Mol Biol 278 (1): 183-194.

Mclaurin J, Franklin T, Zhang X, Deng J AND Fraser PE. 1999. Interactions of Alzheimer amyloid-beta peptides with glycosaminoglycans effects on fibril nucleation and growth. Eur J Biochem 266 (3): 1101-1110.

McLaurin J, Golomb R, Jurewicz A, Antel JP AND Fraser PE. 2000. Inositol stereoisomers stabilize an oligomeric aggregate of Alzheimer amyloid beta peptide and inhibit abeta -induced toxicity. J Biol Chem 275 (24): 18495-18502.

Merlini G, Ascari E, Amboldi N, Bellotti V, Arbustini E, Perfetti V, Ferrari M, Zorzoli I, MariNONE MG AND GARINI P. 1995. Interaction of the anthracycline 4'-iodo-4'-deoxydoxorubicin with amyloid fibrils: inhibition of amyloidogenesis. Proc Natl Acad Sci USA 92 (7): 2959-2963.

Moir RD, Atwood CS, Romano DM, Laurans MH, Huang X, Bush AI, Smith JD and Tanzi RE. 1999. Differential effects of apolipoprotein $\mathrm{E}$ isoforms on metal-induced aggregation of A beta using physiological concentrations. Biochemistry 38 (14): 45954603.

Monji A, Tashiro K, Yoshida I, Hayashi Y and TAshiro N. 1998. Laminin inhibits A beta 40 fibril formation promoted by apolipoprotein $\mathrm{E} 4$ in vitro. Brain Res 796 (1-2): 171-175. 
Mook-Jung I, Joo I, Sohn S, Kwon HJ, Huh K And JUNG MW. 1997. Estrogen blocks neurotoxic effects of beta-amyloid (1-42) and induces neurite extension on B103 cells. Neurosci Lett 235 (3): 101-104.

Moore CL, Diehl TS, Selkoe DJ and Wolfe MS. 2000. Toward the characterization and identification of gamma-secretases using transition-state analogue inhibitors. Ann N Y Acad Sci 920:197-205.

Morgan D, Diamond DM, Gottschall PE, Ugen KE, Dickey C, Hardy J, Duff K, Jantzen P, DiCarlo G, Wilcock D, Connor K, Hatcher J, Hope C, Gordon M And Arendash GW. 2000. A beta peptide vaccination prevents memory loss in an animal model of Alzheimer's disease. Nature 408 (6815): 982-985.

Mucke L, Yu GQ, McConlogue L, Rockenstein EM, Abraham CR and Masliah E. 2000. Astroglial expression of human alpha(1)-antichymotrypsin enhances alzheimer-like pathology in amyloid protein precursor transgenic mice. Am J Pathol 157 (6): 2003-2010.

Mukherjee A, Song E, Ehmann MK, Goodman JP, ST Pyrek J, Estus S and Hersh LB. 2000. Insulysin hydrolyzes amyloid beta peptides to products that are neither neurotoxic nor deposit on amyloid plaques. J Neurosci 20 (23): 8745-8759.

Nilsson LNG, Bales KR, DiCarlo G, Gordon MN, Morgan D, Paul SM and Potter H. 2001. Alpha1-antichymotrypsin promotes beta-sheet amyloid plaque deposition in a transgenic mouse model of Alzheimer's disease. J Neurosci 21 (5): 1444-1451.

Nunan J and Small DH. 2000. Regulation of APP cleavage by alpha-, beta- and gamma-secretases. FEBS Lett 483 (1): 6-10.

Oda T, Wals P, Osterburg HH, Johnson SA, Pasinetti GM, Morgan TE, Rozovsky I, Stine WB, SNyder SW AND Holzman TF. 1995. Clusterin (apoJ) alters the aggregation of amyloid beta-peptide (A beta 142) and forms slowly sedimenting beta complexes that cause oxidative stress. Exp Neurol 136 (1): 2231.

Pappolla MA, Sos M, Omar RA, Bick RJ, HicksonBick DL, Reiter RJ, EFthimiopoulos S AND Robakis NK. 1997. Melatonin prevents death of neuroblastoma cells exposed to the Alzheimer amyloid peptide. J Neurosci 17 (5): 1683-1690.
Pappolla M, Bozner P, Soto C, Shao H, Robakis NK, Zagorski M, Frangione B AND GHiso J. 1998. Inhibition of Alzheimer beta-fibrillogenesis by melatonin. J Biol Chem 273 (13): 7185-7188.

Pappolla Ma, Chyan YJ, Poeggler B, Bozner P, Ghiso J, Ledoux SP ANd WiLson GL. 1999. Alzheimer beta protein mediated oxidative damage of mitochondrial DNA: prevention by melatonin. J Pineal Res 27 (4): 226-229.

Pappolla Ma, Chyan YJ, Poeggeler B, Frangione B, Wilson G, Ghiso J and Reiter RJ. 2000. An assessment of the antioxidant and the antiamyloidogenic properties of melatonin: implications for Alzheimer's disease. J Neural Transm 107 (2): 203231.

Paresce DM, Ghosh RN And Maxfield FR. 1996. Microglial cells internalize aggregates of the Alzheimer's disease amyloid beta-protein via a scavenger receptor. Neuron 17 (3): 553-565.

Pike CJ, Burdick D, Walencewicz AJ, Glabe CG and Cotman CW. 1993. Neurodegeneration induced by beta-amyloid peptides in vitro: the role of peptide assembly state. J Neurosci 13 (4): 1676-1687.

Poduslo JF, Curran GL, Kumar A, Frangione B AND Soto C. 1999. Beta-sheet breaker peptide inhibitor of Alzheimer's amyloidogenesis with increased blood-brain barrier permeability and resistance to proteolytic degradation in plasma. J Neurobiol 39 (3): 371-382.

Price DL, Sisodia SS And Borchelt DR. 1998. Alzheimer disease-when and why? Nat Genet 19 (4): 314316.

Qiu Z, Strickland DK, Hyman BT and Rebeck GW. 1999. Alpha2-macroglobulin enhances the clearance of endogenous soluble beta-amyloid peptide via lowdensity lipoprotein receptor-related protein in cortical neurons. J Neurochem 73 (4): 1393-1398.

Schenk D, Barbour R, Dunn W, Gordon G, Grajeda H, Guido T, Hu K, Huang J, Johnson-Wood K, Khan K, Kholodenko D, Lee M, Liao Z, LieberBurg I, Motter R, Mutter L, Soriano F, Shopp G, Vasquez N, Vandevert C, Walker S, Wogulis M, Yednock T, Games D ANd Seubert P. 1999. Immunization with amyloid-beta attenuates Alzheimerdisease-like pathology in the PDAPP mouse. Nature 400 (6740): 173-177. 
Scheuner D, Eckman C, Jensen M, Song X, Citron M, Suzuki N, Bird TD, Hardy J, Hutton M, Kukull W, Larson E, Levy-Lahad E, Vittanen M, Peskind E, Poorkaj P, Schellenberg G, Tanzi R, Wasco W, Lannfelt L, Selkoe D and Younkin S. 1996. Secreted amyloid beta-protein similar to that in the senile plaques of Alzheimer's disease is increased in vivo by the presenilin 1 and 2 and APP mutations linked to familial Alzheimer's disease. Nat Med 2 (8): 864-870.

Seiffert D, Bradley JD, Rominger CM, Rominger DH, Yang F, Meredith JE JR, Wang Q, Roach AH, Thompson LA, Spitz SM, Higaki JN, Prakash SR, Combs AP, Copeland RA, Arneric SP, Hartig PR, Robertson DW, Cordell B, Stern AM, Olson RE AND ZACZEK R. 2000. Presenilin-1 and -2 are molecular targets for gamma-secretase inhibitors. J Biol Chem 275 (44): 34086-34091.

Selkoe DJ. 1994. Cell biology of the amyloid betaprotein precursor and the mechanism of Alzheimer's disease. Annu Rev Cell Biol 10: 373-403.

SELKOE DJ. 1998. The cell biology of beta-amyloid precursor protein and presenilin in Alzheimer's disease. Trends Cell Biol 8 (11): 447-453.

Selkoe DJ. 1999. Translating cell biology into therapeutic advances in Alzheimer's disease. Nature 399 (6738 Suppl):A23-A31.

Sennvik K, Benedikz E, Fastbom J, Sundstrom E, Winblad B and Ankarcrona M. 2001. Calcium ionophore A23187 specifically decreases the secretion of beta-secretase cleaved amyloid precursor protein during apoptosis in primary rat cortical cultures. J Neurosci Res 63 (5): 429-437.

Seshadri S, Zornberg GL, Derby LE, Myers MW, Jick H and Drachman DA. 2001. Postmenopausal estrogen replacement therapy and the risk of Alzheimer disease. Arch Neurol 58 (3): 435-440.

Shaffer LM, Dority MD, Gupta-Bansal R, FrederICKSON RC, Younkin SG AND BRUNDEN KR. 1995. Amyloid beta protein (A beta) removal by neuroglial cells in culture. Neurobiol Aging 16 (5): 737-745.

Shirotani K, Tsubuki S, Iwata N, Takaki Y, Harigaya W, Maruyama K, Kiryu-Seo S, Kiyama H, Iwata H, Tomita $\mathrm{T}$, Iwatsubo $\mathrm{T}$ and Saido TC. 2001. Neprilysin degrades both amyloid beta peptides 1-40 and 1-42 most rapidly and efficiently among thiorphan- and phosphoramidon-sensitive endopeptidases. J Biol Chem 276 (24): 21895-21901.

Sigurdsson EM, Permanne B, Soto C, Wisniewski T AND FrangIONE B. 2000. In vivo reversal of amyloid-beta lesions in rat brain. J Neuropathol Exp Neurol 59 (1): 11-17.

Sigurdsson EM, Scholtzova H, Mehta PD, FranGIONE B AND WISNIEWSKI T. 2001. Immunization with a nontoxic/nonfibrillar amyloid-beta homologous peptide reduces Alzheimer's disease-associated pathology in transgenic micel Am J Pathol 159 (2): 439-447.

Sinha S, Anderson JP, Barbour R, Basi GS, Caccavello R, Davis D, Doan M, Dovey HF, Frigon N, Hong J, Jacobson-Croak K, Jewett N, Keim P, Knops J, Lieberburg I, Power M, Tan H, Tatsuno G, Tung J, Schenk D, Seubert P, SuomenSAARI SM, Wang S, WaLker D AND John V. 1999. Purification and cloning of amyloid precursor protein beta-secretase from human brain. Nature 402 (6761): 537-540.

Sipe JD. 1992. Amyloidosis. Annu Rev Biochem 61: 947-975.

Skene DJ, Vivien-Roels B, Sparks DL, Hunsaker JC, Pevet P, Ravid D and SwaAb DF. 1990. Daily variation in the concentration of melatonin and 5methoxytryptophol in the human pineal gland: effect of age and Alzheimer's disease. Brain Res 528 (1): $170-174$

Small DH and McLean CA. 1999. Alzheimer's disease and the amyloid beta protein: What is the role of amyloid? J Neurochem 73 (2): 443-449.

Snow AD, Mar H, Nochlin D, Kimata K, Kato M, Suzuki S, Hassell J and Wight TN. 1988. The presence of heparan sulfate proteoglycans in the neuritic plaques and congophilic angiopathy in Alzheimer's disease. Am J Pathol 133 (3): 456-463.

Snow AD, Mar H, Nochlin D, Kresse H and Wight TN. 1992. Peripheral distribution of dermatan sulfate proteoglycans (decorin) in amyloid-containing plaques and their presence in neurofibrillary tangles of Alzheimer's disease. J Histochem Cytochem 40 (1): 105-113.

Snow AD, Kinsella MG, Parks E, Sekiguchi RT, Miller JD, Kimata K and Wight TN. 1995. Differential binding of vascular cell-derived proteogly- 
cans (perlecan, biglycan, decorin, and versican) to the beta-amyloid protein of Alzheimer's disease. Arch Biochem Biophys 320 (1): 84-95.

SNow AD, Nochlin D, SeKiguichi R ANd CARLson SS. 1996. Identification in immunolocalization of a new class of proteoglycan (keratan sulfate) to the neuritic plaques of Alzheimer's disease. Exp Neurol 138 (2): 305-317.

Solomon B, Koppel R, Hanan E and Katzav T. 1996. Monoclonal antibodies inhibit in vitro fibrillar aggregation of the Alzheimer beta-amyloid peptide. Proc Natl Acad Sci USA 93 (1): 452-455.

Solomon B, Koppel R, Frankel D and HananAHARon E. 1997. Disaggregation of Alzheimer beta-amyloid by site-directed mAb. Proc Natl Acad Sci USA 94 (8): 4109-4112.

Soto C, Kindy MS, Baumann M and Frangione B. 1996. Inhibition of Alzheimer's amyloidosis by peptides that prevent beta-sheet conformation. Biochem Biophys Res Commun 226 (3): 672-678.

Soto C, Sigurdsson EM, Morelli L, Kumar RA, Castano EM and Frangione B. 1998. Beta-sheet breaker peptides inhibit fibrillogenesis in a rat brain model of amyloidosis: implications for Alzheimer's therapy. Nat Med 4 (7): 822-826.

Soto C, Kascsak RJ, Saborio GP, Aucouturier P, Wisniewski T, Prelli F, Kascsak R, Mendez E, Harris DA, Ironside J, Tagliavini F, Carp RI AND FRANGIONE B. 2000. Reversion of prion protein conformational changes by synthetic beta-sheet breaker peptides. Lancet 355 (9199): 192-197.

St. George-Hyslop PH and Westaway DA. 1999. Alzheimer's disease. Antibody clears senile plaques. Nature 400 (6740): 116-117.

Steinhilb MS, Turner RS and Gaut JR. 2000. The Protease Inhibitor, MG132, Blocks Maturation of the Amyloid Precursor Protein Swedish Mutant Preventing Cleavage by beta-Secretase. J Biol Chem 276 (6): 4476-4484

Tacnet-Delorme P, Chevallier S and Arlaud GJ. 2001. Beta-amyloid Fibrils Activate the C1 Complex of Complement Under Physiological Conditions: Evidence for a Binding Site for Abeta on the C1q Globular Regions. J Immunol 167 (11): 6374-6381.

TAlesa VN. 2001. Acetylcholinesterase in Alzheimer's disease. Mech Ageing Dev 122 (16): 1961-1969.

Terzi E, Holzemann G and Seelig J. 1994. Alzheimer beta-amyloid peptide 25-35: electrostatic interactions with phospholipid membranes. Biochemistry 33 (23): 7434-7441.

Terzi E, Holzemann G and Seelig J. 1995. Selfassociation of beta-amyloid peptide (1-40) in solution and binding to lipid membranes. J. Mol. Biol. 252 (5): 633-642.

Vassar R, Bennett BD, Babu-Khan S, Kahn S, Mendiaz EA, Denis P, Teplow DB, Ross S, Amarante P, Loeloff R, Luo Y, Fisher S, Fuller J, Edenson S, Lile J, Jarosinski MA, Biere AL, Curran E, Burgess T, Louis JC, Collins F, Treanor J, Rogers G and Citron M. 1999. Beta-secretase cleavage of Alzheimer's amyloid precursor protein by the transmembrane aspartic protease BACE. Science 286 (5440): 735-741.

Vekrellis K, Ye Z, Qiu WQ, Walsh D, Hartley D, Chesneau V, Rosner MR and Selkoe DJ. 2000. Neurons regulate extracellular levels of amyloid betaprotein via proteolysis by insulin-degrading enzyme. J Neurosci 20 (5): 1657-1665.

Verbeek MM, Ruiter DJ and de WaAl RM. 1997. The role of amyloid in the pathogenesis of Alzheimer's disease. Biol Chem 378 (9): 937-950.

Watson DJ, Lander AD and Selkoe DJ. 1997. Heparin-binding properties of the amyloidogenic peptides Abeta and amylin. Dependence on aggregation state and inhibition by Congo red. J. Biol. Chem. 272 (50): 31617-31624

Webster S, Glabe C and Rogers J. 1995. Multivalent binding of complement protein $\mathrm{C} 1 \mathrm{Q}$ to the amyloid beta-peptide (A beta) promotes the nucleation phase of A beta aggregation. Biochem Biophys Res Commun 217 (3): 869-875.

Wisniewski T, Ghiso J and Frangione B. 1991. Peptides homologous to the amyloid protein of Alzheimer's disease containing a glutamine for glutamic acid substitution have accelerated amyloid fibril formation. Biochem Biophys Res Commun 179 (3): $1247-1254$

Wood SJ, Chan W and Wetzel R. 1996. An ApoEAbeta inhibition complex in Abeta fibril extension. Chem Biol 3 (11): 949-956. 
Xu H, Gouras GK, Greenfield JP, Vincent B, Naslund J, Mazzarelli L, Fried G, Jovanovic JN, Seeger M, Relkin NR, Liao F, Checler F, Buxbaum JD, Chait BT, Thinakaran G, Sisodia SS, WANG R, GREENGARd P ANd GANDY S. 1998. Estrogen reduces neuronal generation of Alzheimer betaamyloid peptides. Nat Med 4 (4): 447-451.

Yan R, Bienkowski MJ, Shuck ME, Miao H, Tory MC, Pauley AM, Brashier JR, Stratman NC, Mathews WR, Buhl AE, Carter DB, Tomasselli AG, Parodi LA, Heinrikson RL and Gurney ME. 1999. Membrane-anchored aspartyl protease with Alzheimer's disease beta-secretase activity. Nature 402 (6761): 533-537.

YANG DS, Yip CM, HuANG TH, ChaKrabartTy A AND Fraser PE. 1999. Manipulating the amyloid-beta aggregation pathway with chemical chaperones. J Biol Chem 274 (46): 32970-32974.
YANKNER BA. 1996. Mechanisms of neuronal degeneration in Alzheimer's disease. Neuron 16 (5): 921-932.

Yu G, Nishimura M, Arawaka S, Levitan D, Zhang Ll, Tandon A, Song YQ, Rogaeva E, Chen Fs, Kawaral T, Supala A, Levesque L, Yu H, Yang DS, Holmes E, Millman P, Liang Y, Zhang DM, Xu DH, Sato C, Rogaev E, Smith M, Janus C, Zhang Y, Aebersold R, Farrer L, Sorbi S, Bruni A, Fraser P and St George-Hyslop P. 2000. Nicastrin modulates presenilin-mediated notch/glp-1 signal transduction and betaAPP processing. Nature 407 (6800): 48-54.

Zhang Y, Tounekti O, Akerman B, Goodyer CG AND LeBlanc A. 2001. 17-beta-estradiol induces an inhibitor of active caspases. J Neurosci 21 (20): RC176. 